\title{
Spatial and temporal variation in mercury contamination of seabirds in the North Sea
}

\author{
R. W. Furness ${ }^{1}$, D. R. Thompson ${ }^{1}$ \& P. H. Becker ${ }^{2}$ \\ ${ }^{1}$ Applied Ornithology Unit, Department of Zoology, University of Glasgow; \\ Glasgow G12 8QQ, United Kingdom \\ ${ }^{2}$ Institut für Vogelforschung "Vogelwarte Helgoland"; An der Vogelwarte 21, \\ D-26386 Wilhelmshaven, Germany
}

\begin{abstract}
Once the moult patterns have been taken into account, feather methylmercury levels can be used to accurately measure the mercury burdens of seabirds. We used body feathers from live seabirds and from museum collections to examine geographical and temporal patterns of mercury contamination in the North Sea. This approach identifies an increase in mercury concentrations in seabirds of the German North Sea coast during the last 100 years, especially high levels during the 1940s, and reduced contamination in the last few years. Comparisons among populations suggest that some increases in mercury levels are predominantly due to local pollution inputs, as on the German coast, while in other areas deposition from jet stream circulation of global contamination may be the major contributor. Mercury levels are far higher in seabirds from the German North Sea coast than in populations from the north and west North Sea or from most areas of the North Atlantic. We advocate the use of museum collections of birds for studies of long-term changes in levels of mercury contamination.
\end{abstract}

\section{INTRODUCTION}

Heavy metals are toxic to aquatic organisms and are accumulated by many marine species. Technical advances in measuring, and in procedures for contamination-free sampling and handling of samples, now allow accurate measurement of heavy metal concentrations in water samples. But since this was not possible before the 1970s, data on natural levels of heavy metals in seawater do not exist. Low concentrations of a metal in surface layers of the sea may not indicate a low level of metal pollution, as high levels of biological production will cause rapid assimilation of many metals. The availability of metals to biota depend on whether they are ions in solution, adsorbed onto particles or in organic complexes. In this way, the concentration itself, of a dissolved metal in seawater may not indicate the availability of the metal to marine organisms. As a result, the use of 'biomonitors' has developed. Biomonitors also have the advantage of integrating exposure over time and space, and in some cases allow 'retrospective monitoring' by examination of metal levels in specimens collected in the past.

Many biomonitoring organisms have been used. Molluscs combine many desirable characteristics for monitoring at a very local level (Phillips, 1990), while seabirds can provide information over broader spatial scales (Furness \& Greenwood, 1993). Local 
uptake of mercury by seabirds is clearly seen from analysis of eggs (Becker, 1989, 1991; Becker et al., 1985, 1991). Analysis of mercury in feathers has the specific advantage that there are many dated museum specimens collected up to 150 years ago, which permit comparisons of contemporary and historical levels of mercury (Berg et al., 1966; Walsh, 1990; Thompson et al., 1992a, 1993).

In this paper, we will briefly review the evidence that justifies the use of feathers as monitors of mercury in the marine ecosystem, and then examine the spatial and temporal patterns shown for mercury levels in the North Sea, with particular emphasis on the situation in the German Bight.

\section{FEATHERS AS MONITORS OF MERCURY}

To be useful as a biomonitor, mercury levels in feathers must reflect ecosystem contamination. Mercury in marine invertebrates and small fish (as eaten by seabirds) is mainly methylmercury. Dietary assimilation of methylmercury by birds is consistently very high, though most inorganic mercury ingested is voided in faeces. Mercury is incorporated into feathers as they grow, and this has been shown experimentally to occur in a dose-dependent fashion (Scheuhammer, 1987; Lewis \& Furness, 1991). All the mercury in feathers is methylmercury (Thompson \& Furness, 1989a), and this allows a biochemical fractionation to be used to remove any inorganic mercury that has been deposited onto the feather from the atmosphere, or as dust in a museum drawer. Mercury in feathers is firmly bound to the keratin so that even extreme treatment with UV or heat does not alter the mercury content (Appelquist et al., 1984).

Incorporation of mercury into feathers during their growth appears to be the main route of excretion of mercury from soft tissues. Some mercury is deposited into eggs by females, but in most species this is too little to result in significant differences in feather mercury levels between the sexes (Honda et al., 1986; Furness et al., 1990; Thompson et al., 1991). During the period between moults, mercury is accumulated in the soft tissues of birds and passes into growing feathers during the annual autumn moult (Braune \& Gaskin, 1987a). In a few species, such as large albatrosses, which have infrequent moults, it would appear that much of the methylmercury accumulated in soft tissues is demethylated into inorganic mercury, which is then stored in a nontoxic form bound in the liver (Thompson \& Furness, 1989b). In these species, methylmercury in feathers may not represent mercury uptake.

Feathers grown early in the moult incorporate highest concentrations of mercury; mercury concentration tends to decrease monotonically along feather sequences such as primaries (Furness et al., 1986; Braune, 1987; Braune \& Gaskin, 1987a, b).

For environmental monitoring using feathers, the effects of moult on mercury levels of individual feathers can be minimized by pooling several small body feathers from a defined plumage area away from brood patches (Furness et al., 1986). If nestlings are used, little variation arises from feather growth sequence in some species (Lewis \& Furness, 1991; Thompson et al., 1991). It can be anticipated that in species where feather development occurs late in growth, mercury may accumulate in soft tissues until the opportunity arises for elimination into plumage. In such cases, the highest mercury levels will arise in the parts of the plumage grown first, exhibiting higher levels in down than in subsequently grown feathers. 
The tendency of fully grown birds to excrete the burden of mercury accumulated in soft tissues into plumage at each annual moult means that mercury levels in feathers do not vary with age among adult birds (Furness et al., 1990; Thompson et al., 1991). However, levels of mercury are usually higher in feathers of adult birds (representing accumulation for almost one year) than in feathers of chicks (representing mercury intake during their growth, plus any in the egg) (Hoffman \& Curnow, 1979; Lindberg \& Odsjo, 1983; Honda et al., 1985; Thompson et al., 1991). An exception to this though, was found in common terns Sterna hirundo from the German North Sea coast (Thompson et al., 1993), where egg mercury levels are very high (Becker 1991). For monitoring purposes it is important to separate samples into first year and older birds.

For long-term comparisons, it is important that the diet remains the same, since mercury levels vary among prey species. This could be a serious confounding effect. It may be possible to detect changes in trophic relationships by analysis of stable isotope ratios, especially of nitrogen, in feather samples (Hobson \& Welch, 1992; Rau et al., 1992). Species with a broad diet may best represent mercury levels in the ecosystem, but may be more likely than stenophagous species to show variations due to changes in diet composition.

Migratory birds or birds with large foraging ranges may be less suitable as biomonitors than non-migratory birds with short foraging ranges. Nevertheless, the former species can be useful as indicators of spatial trends in mercury contamination (see Table 1). Feathers from chicks or recent fledglings will be most clearly representative of the location where the chicks were reared, but will represent a more restricted period of time - from hatching to fledging. In small chicks, the mercury levels may be influenced by the mercury content of the egg as much as by the mercury in their food.

\section{MATERIALS AND METHODS}

Samples of 4-10 body feathers were taken from study skins in museums (Institut für Vogelforschung, Wilhelmshaven; Naturwissenschaftliches Museum, Osnabrück; Niedersächsisches Landesmuseum, Hannover; Senckenbergmuseum, Frankfurt; Staatliches Museum für Naturkunde, Stuttgart; Staatliches Museum für Naturkunde und Vorgeschichte, Oldenburg; Staatliches Naturhistorisches Museum, Braunschweig; Überseemuseum, Bremen; Zoologisches Forschungsinstitut und Museum Alexander Koenig, Bonn; Zoologisches Institut und Museum, Hamburg) and from live birds caught at colonies in the German Bight and in East Scotland and Shetland. Some freshly dead terns found at colonies on the German North Sea coast in 1988-90 were also available for analysis.

Feather samples were washed to remove gross surface contamination, and museum samples were subjected to an organic mercury extraction to remove any remaining inorganic mercury contamination (Thompson \& Furness, 1989a). Liver and kidney tissues were oven dried at ca $60^{\circ} \mathrm{C}$ to constant mass. Acid digested samples were then oxidized with potassium permanganate to convert methylmercury to $\mathrm{Hg}^{++}$ions, and mercury levels were determined by a cold vapour technique. Further details of the methods and tests of their reliability are provided in Furness et al. (1986). Thompson \& Furness (1989a, b), Lewis et al. (1993). Statistical tests were two-tailed, and the level of significance was $\mathrm{p}<0.05$. 


\section{RESULTS}

Numbers of study skins collected on the German North Sea coast varied among species (Table 1). High levels of individual variation in mercury concentrations and small sample sizes, together with clumped distributions of samples over the decades, precluded analysis of historical trends for guillemot, Uria aalge, or kittiwake, Rissa tridactyla. However, changes were statistically significant for the herring gull and the common tern. The results showed that the mercury levels of post-1940 were about twice as high as pre1940 levels for adult herring gulls, and juvenile common terns (Table 1), and also for herring gull chicks and adult common terns (Thompson et al., 1993).

A more complicated pattern of variation was evident in the data for adult herring gulls, for which the largest sample sizes were available (Fig. 1). Notwithstanding the variation between decades (1-way ANOVA of mercury concentration by decade $f_{9,130}=$ $12.1, \mathrm{p}<0.001)$, a considerably higher level of mercury was found in adult and young German herring gulls than in conspecifics from East Scotland or Shetland (Fig. 1, Table 1). Indeed, levels of mercury in each species from the German Bight were consistently higher than the levels found in conspecifics from populations elsewhere (Table 1 and Thompson et al., 1992a, b). Mercury levels in body feathers of adult common terns from the German North Sea coast were also higher than those found in this species in the Azores (1.57 $\mathrm{\mu g} \mathrm{g}^{-1}$; Monteiro, unpubl. data) or Long Island (1.4 $\mathrm{g} \mathrm{g} \mathrm{g}^{-1}$; Gochfeld, 1980).

Comparisons between colonies at the Elbe and the Jade showed that mercury contamination was much higher among chicks reared at the Elbe (Table 2). It would appear that despite these high levels of organic mercury, no detectable demethylation had occurred, since the measured concentration of methylmercury in livers was approximately the same as the measured concentration of total mercury in each sample (Fig. 2).

\section{DISCUSSION}

\section{Intraspecific variation in mercury concentrations}

Mercury levels in feathers showed high variation among individuals in population samples, with a tendency for the data to be skewed, including a few birds containing particularly high concentrations (Table 1). Such results are typical of mercury studies of seabirds (Walsh, 1990) and may arise as a result of individual specializations in diet or from differences in the opportunities of birds to excrete mercury. The extensive individual variation makes it necessary to have large samples in order to test for differences between groups. Unfortunately, for many species the numbers of study skins in museums are too small to permit this, and so comparisons over decades are limited to the birds collected in largest numbers, which are not necessarily the most common species.

\section{Temporal patterns of mercury pollution}

Despite pluvial inputs of mercury to the world's oceans being estimated to be about an order of magnitude greater than those from fluvial sources (Gill \& Fitzgerald, 1987), river systems heavily contaminated with pollutants can have a substantial local impact. Several large rivers which have passed through some of the most densely industrialized 
Table 1. Comparisons of mercury levels ( $\mu \mathrm{g} \mathrm{g}^{-1}$ feather) in body feathers of gulls, common terns, and guillemots from populations in the German Bight, East Scotland and Shetland, sampled before 1940 or after 1940, showing significant regional variations in all species (in each case German Bight $>$ East Scotland > Shetland; Student-Newman-Keuis range tests). Values given are arithmetic mean, standard deviation (s.d.), median, range and sample size (n). For all groups, except herring gulls on the German North Sea coast, samples were all from birds collected during the breeding season.

Note: L. B.-b. gull is Lesser black-backed gull Larus fuscus

\begin{tabular}{|c|c|c|c|c|c|}
\hline $\begin{array}{l}\text { Species: Age } \\
\text { and period }\end{array}$ & & & German Bight & $\begin{array}{c}\text { Locality } \\
\text { East Scotland }\end{array}$ & Shetland \\
\hline $\begin{array}{l}\text { Herring gull } \\
\text { after } 1940\end{array}$ & adult & $\begin{array}{l}\text { mean } \\
\text { s. d. } \\
\text { median } \\
\text { range } \\
\mathrm{n}\end{array}$ & $\begin{array}{c}7.91 \\
3.86 \\
7.34 \\
2.15-21.18 \\
113\end{array}$ & $\begin{array}{c}2.60 \\
0.93 \\
2.38 \\
1.45-4.66 \\
26\end{array}$ & $\begin{array}{l}- \\
- \\
- \\
- \\
-\end{array}$ \\
\hline $\begin{array}{l}\text { Herring gull } \\
\text { before } 1940\end{array}$ & adult & $\begin{array}{l}\text { mean } \\
\text { s.d. } \\
\text { median } \\
\text { range } \\
\text { n }\end{array}$ & $\begin{array}{c}4.56 \\
1.97 \\
4.19 \\
1.03-7.83 \\
27\end{array}$ & $\begin{array}{l}- \\
- \\
- \\
- \\
-\end{array}$ & $\begin{array}{l}- \\
- \\
- \\
-\end{array}$ \\
\hline $\begin{array}{l}\text { Herring gull } \\
\text { after } 1940\end{array}$ & chick & $\begin{array}{l}\text { mean } \\
\text { s.d. } \\
\text { median } \\
\text { range } \\
n\end{array}$ & $\begin{array}{c}5.88 \\
4.90 \\
4.25 \\
0.78-27.14 \\
38\end{array}$ & $\begin{array}{l}- \\
- \\
- \\
-\end{array}$ & $\begin{array}{c}2.24 \\
0.83 \\
2.07 \\
1.04-4.12 \\
12\end{array}$ \\
\hline $\begin{array}{l}\text { L. B.-b. gull } \\
\text { after } 1940\end{array}$ & adult & $\begin{array}{l}\text { mean } \\
\text { s. d. } \\
\text { median } \\
\text { range } \\
n\end{array}$ & $\begin{array}{l}- \\
- \\
- \\
-\end{array}$ & $\begin{array}{c}3.79 \\
1.99 \\
3.15 \\
1.86-11.49 \\
30\end{array}$ & $\begin{array}{l}- \\
- \\
- \\
-\end{array}$ \\
\hline $\begin{array}{l}\text { Common tern } \\
\text { after } 1940\end{array}$ & chick & $\begin{array}{l}\text { mean } \\
\text { s. d. } \\
\text { median } \\
\text { range } \\
n\end{array}$ & $\begin{array}{c}12.89 \\
6.90 \\
6.80 \\
1.51-70.00 \\
27\end{array}$ & $\begin{array}{c}1.80 \\
0.79 \\
1.65 \\
0.92-3.11 \\
19\end{array}$ & $\begin{array}{c}1.40 \\
0.72 \\
1.38 \\
0.84-2.95 \\
12\end{array}$ \\
\hline $\begin{array}{l}\text { Common tern } \\
\text { before } 1940\end{array}$ & chick & $\begin{array}{l}\text { mean } \\
\text { s. d. } \\
\text { median } \\
\text { range } \\
n\end{array}$ & $\begin{array}{c}2.49 \\
1.03 \\
2.02 \\
0.37-4.87 \\
27\end{array}$ & $\begin{array}{l}- \\
- \\
- \\
- \\
-\end{array}$ & $\begin{array}{l}- \\
- \\
- \\
- \\
-\end{array}$ \\
\hline $\begin{array}{l}\text { Kittiwake } \\
\text { after } 1940\end{array}$ & adult & $\begin{array}{l}\text { mean } \\
\text { s. d. } \\
\text { median } \\
\text { range } \\
\mathrm{n}\end{array}$ & $\begin{array}{c}10.06 \\
1.42 \\
10.48 \\
8.48-11.23 \\
3\end{array}$ & $\begin{array}{c}3.80 \\
1.70 \\
3.77 \\
0.70-9.50 \\
46\end{array}$ & $\begin{array}{c}2.90 \\
0.90 \\
2.81 \\
1.60-5.20 \\
42\end{array}$ \\
\hline $\begin{array}{l}\text { Kittiwake } \\
\text { after } 1940\end{array}$ & chick & $\begin{array}{l}\text { mean } \\
\text { s. d. } \\
\text { median } \\
\text { range } \\
n\end{array}$ & $\begin{array}{c}2.65 \\
0.61 \\
2.86 \\
1.61-3.64 \\
13\end{array}$ & $\begin{array}{l}- \\
- \\
- \\
-\end{array}$ & $\begin{array}{c}0.49 \\
0.28 \\
0.36 \\
0.26-1.03 \\
9\end{array}$ \\
\hline $\begin{array}{l}\text { Guillemot } \\
\text { after } 1940\end{array}$ & adult & $\begin{array}{l}\text { mean } \\
\text { s. d. } \\
\text { median } \\
\text { range } \\
n\end{array}$ & $\begin{array}{c}6.13 \\
4.14 \\
5.50 \\
2.25-13.80 \\
6\end{array}$ & $\begin{array}{c}3.80 \\
3.20 \\
3.04 \\
1.10-15.40 \\
44\end{array}$ & $\begin{array}{c}1.20 \\
0.40 \\
1.01 \\
0.30-2.40 \\
56\end{array}$ \\
\hline $\begin{array}{l}\text { Guillemot } \\
\text { before } 1940\end{array}$ & adult & $\begin{array}{l}\text { mean } \\
\text { s. d. } \\
\text { median } \\
\text { range } \\
\text { n }\end{array}$ & $\begin{array}{c}9.18 \\
3.49 \\
7.93 \\
3.66-16.20 \\
19\end{array}$ & $\begin{array}{l}- \\
- \\
- \\
-\end{array}$ & $\begin{array}{l}- \\
- \\
- \\
-\end{array}$ \\
\hline
\end{tabular}




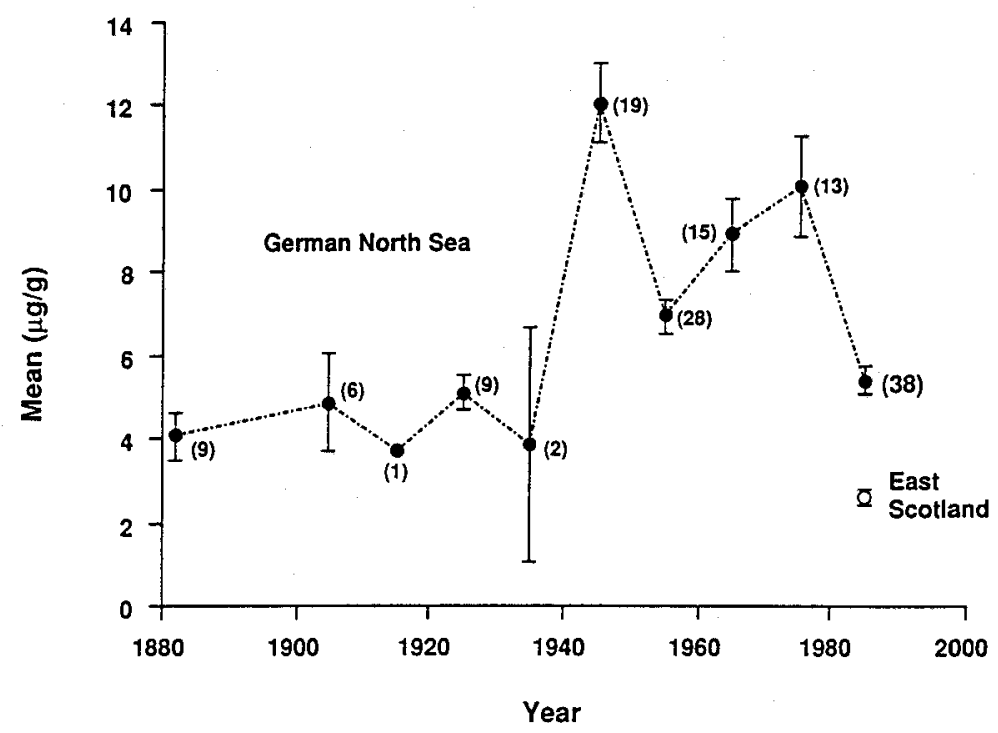

Fig. 1. Mercury levels $\left(\mu \mathrm{g} \mathrm{g}^{-1}\right)$ in body feathers of adult herring gulls from the German North Sea coast from 1880 to 1990 . The figures shown are arithmetic means (dots) and one standard error. Mean concentration (and one standard error) of mercury in body feathers of herring gulls from East Scotland is shown with an open circle $(n=26,1986)$

areas of Europe flow into the North Sea along the German coast, notable amongst these being the river Elbe. Common tern eggs from the Elbe estuary and from the inner German Bight are characterized by much higher mercury levels than those from the East and North Frisian Islands (Becker et al., 1985, 1992; Becker, 1991). During the 1980s, the Elbe transported 7-25 tonnes of mercury per year (Umweltbundesamt, 1989) which amounts to $40 \%$ of the riverborne and to about $10 \%$ of the total input of mercury into the

Table 2. Mercury levels in body feathers, flight feathers, liver and kidney of common tern chicks and in down samples from small chicks, from colonies in the Elbe and the Jadebusen sampled in 1988-1991. See explanations for values given in Table 1

\begin{tabular}{|llcccc|}
\hline \multirow{2}{*}{ Colony } & \multicolumn{4}{c}{ Mercury concentration $\left(\mu \mathrm{g} \mathrm{g}^{-1}\right.$ dry mass) } \\
& Tissue & Sample size & Mean & s.d. & Range \\
\hline \multirow{2}{*}{ Elbe } & Down & 1 & 75.7 & - & - \\
& Body feathers & 4 & 36.4 & 18.9 & $21.7-62.9$ \\
& Primaries & 4 & 32.0 & 13.2 & $18.0-48.0$ \\
& Liver & 4 & 11.9 & 11.6 & $4.3-29.0$ \\
& Kidney & 4 & 9.9 & 5.9 & $5.5-18.4$ \\
Jadebusen & Down & 19 & 6.0 & 1.8 & $2.7-9.6$ \\
& Body feathers & 9 & 3.8 & 0.7 & $2.9-5.1$ \\
& Primaries & 1 & 4.0 & - & - \\
& Liver & 3 & 2.2 & 1.0 & $1.1-2.9$ \\
& Kidney & 2 & 2.8 & 1.9 & $1.4-4.2$ \\
\hline
\end{tabular}




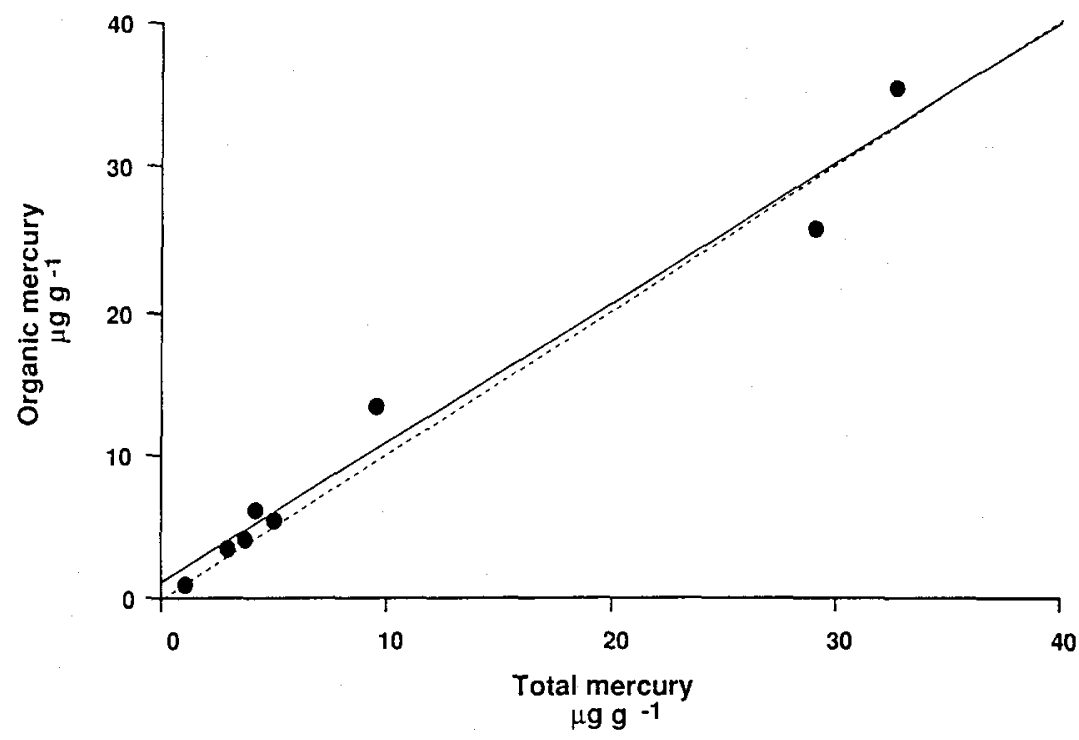

Fig. 2. Concentration of organic (methyl) mercury in relation to the concentration of total mercury (both as $\mu \mathrm{g} \mathrm{Hg} \mathrm{g}^{-1}$ dry mass) measured in livers of dead common tern chicks from colonies on the German North Sea coast in 1990. The solid line shows the regression $y=1.06+0.98 x$ and the dotted line shows the predicted relationship if all the mercury in the liver is in the organic form

North Sea (Anon., 1987). The pollution of Rhine sediments increased especially during the 1960s and early 1970s (Salomons \& Förstner, 1984), when this river's load was 70 tonnes of mercury per year (Rat von Sachverständigen für Umweltfragen, 1976) - the same amount as the total input of mercury to the North Sea during the 1980s (Wissenschaftlich-Technische Arbeitsgruppe, 1987). Thereafter, through measures to control mercury emissions, the load of the Rhine decreased to 6.3 tonnes of mercury per year in the 1980s (Anon., 1987). From 1969-1976 the total consumption of mercury by industry in the Federal Republic of Germany was between 378 and 808 tonnes per year (Bundesminister des Innern, 1971; Kaiser \& Tölg, 1980) before it dropped to 250 tonnes per year in the 1980s (Bundesminister des Innern, 1984). Data on the use of mercury in the Federal Republic of Germany from 1952-1990 are summarized in Table 3.

In contrast to the recent reduction in the mercury load of the Rhine, mercury in the Elbe increased further in the 1980s (Umweltbundesamt, 1989) owing to a lack of emission controls in the former German Democratic Republic and Czechoslovakia.

Our results show that mercury levels in the herring gulls did not increase linearly during this century. We find two main phases of increase: initially during the 1940 s and then, after a sharp decline in mercury levels in the 1950s, a prolonged increase during the 1960s and 1970s (Fig. 1). The first peak may be explained by the additional input of heavy metals during the Second World War. Ignition devices of ammunition, mines and bombs contained mercury. Also, industrial production in Germany was unlikely to have been concerned with pollution control at that time. The second increase can be explained by the increasing industrialization in European countries after the Second World War. In the 
Table 3. Mean yearly amount (in tonnes) of mercury available for use in the Federal Republic of Germany 1952-1990. (Data from Import-Export; Statistisches Bundesamt, Wiesbaden, Fachserie 7: „Außenhandel “, Reihe 2)

\begin{tabular}{|llr|}
\hline Period & $\begin{array}{l}\text { Mercury available for use (tonnes) } \\
\text { mean }\end{array}$ & \begin{tabular}{c} 
range \\
\hline $1952-1960$
\end{tabular} \\
$1961-1970$ & 533 & $389-838$ \\
$1971-1980$ & 664 & $186-632$ \\
$1981-1990$ & 392 & $11-301$ \\
\hline
\end{tabular}

Federal Republic of Germany, the use of mercury was highest during the 1960s and dropped to far lower levels in the 1980s (Table 3). Accordingly, Becker et al. (1992) found indications of reduced mercury levels in common tern eggs from the Elbe estuary in 1989 and 1990. Lower levels of mercury in herring gull feathers collected in 1990 (Fig. 1, and Lewis et al., 1993) seem to point in the same direction. While eggs provide a measure of mercury taken up by seabirds in a period of some days before egg-laying, mercury levels in feathers represent uptake of mercury over the period between moults (Furness et al., 1986) and so provide a complementary picture. Continuing use of seabirds as monitors of mercury pollution of the North Sea coastal regions will provide a valuable measure of the effectiveness of pollution reduction programmes.

\section{Spatial variation in mercury loadings}

All of the seabirds examined show higher levels of mercury in the population of the German Bight than in populations from East Scotland or Shetland (Table 1). Furthermore, the higher levels in seabirds from the German Bight seem to apply equally in the historical samples. Herring gulls from the German coast had consistently higher mercury levels from 1850 to 1940 than found in contemporary samples of herring gulls from East Scotland (Fig. 1), and the same is true of guillemots and common terns (Table 1). In some areas, herring gulls now feed extensively on terrestrial foods (especially garbage) and this is likely to have a lower mercury content than found in marine prey. It should follow that an increased use of terrestrial food would lead to a reduction in mercury accumulation. The lower mercury level in herring gulls from East Scotland might be attributable to a more terrestrial diet. The mercury level in lesser black-backed gulls from East Scotland is higher than the level in herring gulls, but is still only half the level found in German herring gulls (Table 1). Differences in mercury levels in guillemots and kittiwakes from Scotland and Germany are pronounced. Clearly the German Bight has contained for a long time higher levels of mercury in the marine food web than have been present in the northern and north-western North Sea.

\section{Effects of diet}

On the southern North Sea coast, at least during the breeding season, both herring gulls and common terns feed inshore; common terns mainly on small fish and crustaceans 
(Boecker, 1967; Becker et al., 1987; Frank, 1992), herring gulls predominantly on mussels Mytilus edulis, crustaceans and fish (Noordhuis \& Spaans, 1992). The preferred feeding area is the Wadden Sea. In this way, the mercury levels of their body feathers directly reflect changes in levels of mercury entering the North Sea ecosystem. This has previously been shown to be the case for eggs, despite the long-distance migrations of common terns (Becker et al., 1991). However, changes in diet composition between years (Becker et al., 1987) will add variance to mercury levels in samples gathered over long periods, while changes in diet over decades (Noordhuis \& Spaans, 1992) may cause systematic bias that affects the interpretation of long term trends in feather mercury levels. We believe that the latter problem may be overcome by sampling diet composition of the study species, or for historical samples, by analysis of stable isotope ratios in feathers to detect changes in trophic relationships over time.

\section{Chick feathers for local comparisons}

On the German North Sea coast, distinct microgeographic differences in mercury contamination were found by means of egg analysis (Becker 1991, Becker et al. 1985, 1992). The distinct differences in mercury contamination between the Elbe and Jade were also evident from analysis of mercury concentrations in common tern chick feathers, showing the utility of these in assessing local 'hotspots' of mercury contamination. Such a facility is not provided by feathers from adult birds in museums; those failed to resolve any significant spatial variation in mercury levels between regions of the German North Sea coast (Thompson et al., 1993).

\section{Possible toxic hazards}

Mercury levels in common tern chicks from the Elbe are considerabiy higher than the levels at which toxic effects become evident in terrestrial and freshwater birds (Scheuhammer, 1987). Despite the very high levels of mercury deposited in feathers and also retained in tissues (Table 2), there was no evidence that the chicks demethylated organic mercury into a less toxic inorganic form (Fig. 2), as some seabirds are believed to be able to do (Thompson \& Furness, 1989b). It is not known whether common terns have such an ability, or whether even these exceptionally high mercury levels are below toxic thresholds for this species. One approach to this question would be to sample feathers from individual adults and to monitor breeding performance in relation to the mercury burden of the individual (Thompson et al., 1991). Similarly, it would be possible to examine mercury burdens of individual chicks and relate these to growth and survival.

Acknowledgements. This research was funded by the British Council and DAAD collaborative research programme, NERC grant GR3/7411, the Nuffield Foundation, the University of Glasgow and the Institut für Vogelforschung, Wilhelmshaven. We thank the staff of the museums mentioned above for making feather samples available from study skin collections. Most feather sampling in German museums was done by F. Büsing and $M$. Wagener. 


\section{LITERATURE CITED}

Anonymous, 1987. Quality status of the North Sea. Dep. Environm., London, $88 \mathrm{pp.}$

Appelquist, H., Asbirk, S. \& Drabaek, I., 1984. Mercury monitoring: mercury stability in bird feathers. - Mar. Pollut. Bull. 15, 22-24.

Becker, P. H., 1989. Seabirds as monitor organisms of contaminants along the German North Sea coast. - Helgoländer Meeresunters. 43, 395-403.

Becker, P. H., 1991. Population and contamination studies in coastal birds: the common tern Sterna hirundo. In: Bird population studies: relevance to conservation and management. Ed. by C. M. Perrins, J. D. Lebreton \& G. J. M. Hirons. Oxford Univ. Press, Oxford, 433-460.

Becker, P. H., Ternes, W. \& Rüssel, H. A., 1985. Schadstoffe in Gelegen von Brutvögeln der deutschen Nordseeküste. II: Quecksilber. - J. Orn. 126, 253-262.

Becker, P. H., Frank, D. \& Walter, U., 1987. Geographische und jährliche Variation der Ernährung der Flußseeschwalbe (Sterna hirundo) an der Nordseeküste. - J. Orn. 128, 457-475.

Becker, P. H., Koepff, C., Heidmann, W. A. \& Büthe, A., 1991. Schadstoffmonitoring mit Seevögeln. Texte, Umweltbundesamt 1992 (2), 1-260.

Becker, P. H., Heidmann, W. A., Büthe, A., Frank, D. \& Koepff, C., 1992. Umweltchemikalien in Eiern von Brutvögeln der deutschen Nordseeküste: Trends 1983-1990. - J. Orn. 133, 109-124.

Berg, W., Johnels, A., Sjostrand, B. \& Westermark, T., 1966. Mercury content in feathers of Swedish birds from the past 100 years. - Oikos 17, 71-83.

Boecker, M., 1967. Vergleichende Untersuchungen zur Nahrungs- und Nistökologie der Flußseeschwalbe (Sterna hirundo L.) und der Küstenseeschwalbe (Sterna paradisaea Pont.). - Bonn. zool. Beitr. 18, 15-126.

Braune, B. M., 1987. Comparison of total mercury levels in relation to diet and molt for nine species of marine birds. - Archs environ. Contam. Toxicol. 16, 217-224.

Braune, B. M. \& Gaskin, D. E., 1987 a. A mercury budget for the Bonaparte's gull during autumn molt. - Ornis scand. 18, 244-250.

Braune, B. M. \& Gaskin, D. E., 1987b. Mercury levels in Bonaparte's gulls (Larus philadelphia) during autumn molt in the Quoddy Region, New Brunswick, Canada. - Archs environ. Contam. Toxicol. $16,539-549$.

Bundesminister des Innern (Hrsg.). 1971. Materialien zum Umweltprogramm der Bundesregierung 1971. Deutscher Bundestag, Bonn, 661 pp.

Bundesminister des Innern (Hrsg.), 1984. Was sie schon immer über Wasser und Umwelt wissen wollten. Kohlhammer, Stuttgart, $192 \mathrm{pp}$.

Frank, D., 1992. The influence of feeding conditions on food provisioning of chicks in common terns Sterna hirundo nesting in the German Wadden Sea. - Ardea 80, 45-55.

Furness, R. W. \& Greenwood, J. J. D., 1993. Birds as monitors of environmental change. Chapman \& Hall, London, $356 \mathrm{pp}$.

Furness, R. W., Muirhead, S. J. \& Woodburn, M., 1986. Using bird feathers to measure mercury in the environment: relationships between mercury content and moult. - Mar. Pollut. Bull. 17, 27-30.

Furness, R. W., Lewis, S. A. \& Mills, J. A., 1990. Mercury levels in the plumage of red-billed gulls Larus novaehollandiae scopulinus of known sex and age, - Environ. Pollut. 63, 33-39.

Gill, G. A. \& Fitzgerald, W. F., 1987. Mercury in the surface waters of the open ocean. - Global biogeochem. Cycles 1, 199-212.

Gochfeld, M., 1980. Tissue distribution of mercury in normal and abnormal young common terns. Mar. Pollut. Bull. 11, 362.

Hobson, K. A. \& Welch, H. E., 1992. Determination of trophic relationships within a high arctic marine food web using $\delta^{13} \mathrm{C}$ and $\delta^{15} \mathrm{~N}$ analysis. - Mar. Ecol. Prog. Ser. 84, 9-18.

Hoffman, R. D. \& Curnow, R. D., 1979, Mercury in herons, egrets and their foods. - J. Wildl. Mgmt. $43,85-93$.

Honda, K., Min, B. Y. \& Tatsukawa, R., 1985. Heavy metal distribution in organs and tissues of the eastern great white heron Egretta alba modesta. - Bull. environ. Contam. Toxicol, 35, 781-789.

Honda, K, Nasu, T. \& Tatsukawa, R., 1986. Seasonal changes in mercury accumulation in the blackeared kite, Milvus migrans lineatus. - Environ. Pollut. 42A, 325-334.

Kaiser, G. \& Tölg, G., 1980. Mercury. In: The handbook of environmental chemistry. Ed. by O. Hutzinger. Springer, Berlin, 3A, 1-58. 
Lewis, S. A. \& Furness, R. W., 1991. Mercury accumulation and excretion in laboratory reared blackheaded gull Larus ridibundus chicks. - Archs environ. Contam. Toxicol. 21, 316-320.

Lewis, S. A., Becker, P. H. \& Furness, R. W., 1993. Mercury levels in eggs, tissues and feathers of herring gulls Larus argentatus from the German Wadden Sea coast. - Environ. Pollut. 80, 293-299.

Lindberg, P. \& Odsjo, T., 1983. Mercury levels in feathers of peregrine falcons Falco peregrinus compared with total mercury content of some of its prey species in Sweden. - Environ. Pollut. 5B, $297-318$.

Noordhuis, R. \& Spaans, A. L., 1992. Interspecific competition for food between herring Larus argentatus and lesser blackbacked gulls $L$. fuscus in the Dutch Wadden Sea area. - Ardea 80 , 115-132.

Phillips, D. J. H., 1990. Use of macroalgae and invertebrates as monitors of metal levels in estuaries and coastal waters. In: Heavy metals in the marine environment. Ed. by R. W. Furness \& P. S. Rainbow. CRC Press, Boca Raton, 81-100.

Rat von Sachverständigen für Umweltfragen (Hrsg.), 1976. Umweltprobleme des Rheins. Kohlhammer, Stuttgart, 258 pp.

Rau, G. H., Ainley, D. G., Bengtson, J. L., Torres, J. J. \& Hopkins, T. L., $1992 .{ }^{15} \mathrm{~N} /{ }^{14} \mathrm{~N}$ and ${ }^{13} \mathrm{C} /{ }^{12} \mathrm{C}$ in Weddell Sea birds, seals, and fish: implications for diet and trophic structure. - Mar. Ecol. Prog. Ser. 84, 1-8.

Salomons, W. \& Förstner, U., 1984. Metals in the hydrocycle. Springer, Berlin, $349 \mathrm{pp}$.

Scheuhammer, A. M., 1987. The chronic toxicity of aluminium, cadmium, mercury and lead in birds: a review. - Environ. Pollut. 46, 263-295.

Thompson, D. R. \& Furness, R. W., 1989a. Comparison of the levels of total and organic mercury in seabird feathers. - Mar. Pollut. Bull. 20, 577-579.

Thompson, D. R. \& Furness, R. W., 1989b. Differences in the chemical form of mercury stored in south Atlantic seabirds. - Environ. Pollut. 60, 305-317.

Thompson, D. R., Hamer, K. H. \& Furness, R. W., 1991. Mercury accumulation in great skuas Catharacta skua of known age and sex, and its effects upon breeding and survival. - J. appl. Ecol. $28,672-684$

Thompson, D. R., Furness, R. W. \& Walsh, P. M., 1992a. Historical changes in mercury concentrations in the marine ecosystem of the north and north-east Atlantic Ocean as indicated by seabird feathers. - J. appl. Ecol. 29, 79-84.

Thompson, D. R., Furness, R. W. \& Barrett, R. T., 1992b. Mercury concentrations in seabirds from colonies in the north-east Atlantic. - Archs environ. Contam. Toxicol. 23, 383-389.

Thompson, D. R., Becker, P. H. \& Furness, R. W., 1993. Long-term changes in mercury concentrations in herring gulls Larus argentatus and common terns Sterna hirundo from the German North Sea coast. - J. appl. Ecol. 30, 316-320.

Umweltbundesamt (Hrsg.), 1989. Daten zur Umwelt 1988/89. Schmidt, Berlin, 613 pp.

Walsh, P. M., 1990. The use of seabirds as monitors of heavy metals in the marine environment. In: Heavy metals in the marine environment. Ed. by R. W. Furness \& P. S. Rainbow. CRC Press, Boca Raton, 183-204. 